\title{
(3) Loop L2 (even level) type IIS cloning - pCs-ye vectors
}

\author{
Eftychis Frangedakis ${ }^{1}$, Susana Sauret-Gueto ${ }^{2}$, Anthony West $^{2}$, \\ Marta Tomaselli ${ }^{3}$, Nicola Patron ${ }^{2}$, Marius Rebmann², \\ Jim Haseloff ${ }^{2}$ \\ ${ }^{1}$ University of Cambridge; \\ 2Plant Sciences, University of Cambridge, OpenPlant; \\ 3University of Cambridge, Open Plant
}

OpenPlant Project

\section{open ठaccess}

\section{DOI:}

dx.doi.org/10.17504/protocol s.io.4wcgxaw

\section{Protocol Citation: Eftychis} Frangedakis, Susana SauretGueto, Anthony West, Marta Tomaselli, Nicola Patron, Marius Rebmann, Jim Haseloff 2019. Loop L2 (even level) type IIS cloning - pCs-ye vectors. protocols.io https://dx.doi.org/10.17504/p rotocols.io.4wcgxaw

License: This is an open access protocol distributed under the terms of the Creative Commons Attribution License, which permits unrestricted use, distribution, and reproduction in any medium, provided the original author and source are credited

Protocol status: Working We use this protocol and it's working

Created: Jun 28, 2019

Last Modified: Sep 24, 2019

PROTOCOL integer ID: 25252

\section{Eftychis Frangedakis}

University of Cambridge, Plant Sciences

\section{ABSTRACT}

Protocol based on

Pollak B, Cerda A, Delmans M, et al (2019) Loop assembly: a simple and open system for recursive fabrication of DNA circuits. New Phytol 222:628-640

https://doi.org/10.1111/nph.15625

\section{MATERIALS}

\section{MATERIALS}

88 Sterile water Contributed by users

88 dATP, 100mM, 25uMoles Promega Catalog \#U1205

88 BSA, molecular biology grade, $20 \mathrm{mg} / \mathrm{ml}$ New England Biolabs Catalog \# B9000S

88 Tango Buffer Thermo Fisher Scientific Catalog \#BY5

88 T4 DNA ligase Thermo Fisher Scientific Catalog \#15224041

88 Lgul (Sapl) Thermo Fisher Scientific Catalog \#ER1931

1 Determine DNA parts concentration with spectrophotometry (Nanodrop). 
2 Prepare aliquots for DNA parts to be assembled at a concentration of $15 \mathrm{nM}$ and of the pCs-pe vector at a concentration of $7.5 \mathrm{nM}$.

To calculate the concentration needed for each part to assemble (not the backbone) in $\mathrm{ng} / \mu \mathrm{L}$, divide the length of the plasmid where they are cloned by 100 . For the backbone, divide the plasmid length by 200 . In this way you can prepare aliquots of your parts and backbones and add $1 \mu \mathrm{L}$ of each one to the plasmid mix.

3 Prepare the Loop assembly Even Level reaction MM according to according to Table

\begin{tabular}{|l|c|}
\hline Component & $\begin{array}{l}\text { Volu } \\
\text { me } \\
(\mu \mathrm{L})\end{array}$ \\
\hline Sterile water & 2 \\
\hline $\begin{array}{l}\text { 10x Tango buffer (Thermo } \\
\text { Fisher) }\end{array}$ & 1 \\
\hline $\begin{array}{c}1 \mathrm{mg} / \mathrm{mL} \text { bovine serum } \\
\text { albumin } \\
\text { (NEB) }\end{array}$ & 0.5 \\
\hline $\begin{array}{l}\text { T4 DNA ligase (5 U/ } \mu \mathrm{L}) \\
(\text { Thermo Fisher) }\end{array}$ & 0.25 \\
\hline \begin{tabular}{l} 
10mM ATP (SIGMA) \\
\hline $\begin{array}{c}\text { Sapl (Lgul) (5 U/ } \mu \mathrm{L})(\text { Thermo } \\
\text { Fisher) }\end{array}$
\end{tabular} & 0.25 \\
\hline Final volume & 5 \\
\hline
\end{tabular}

4 Prepare plasmids mix for each reaction, by adding in a $0.2 \mathrm{~mL}$ tube, $1 \mu \mathrm{L}$ of each DNA part aliquot (see step 2), $1 \mu \mathrm{L}$ of the pCs-pe vector and sterile water up to $5 \mu \mathrm{L}$. Mix well.

5 Add $5 \mu \mathrm{L}$ of master mix to the $5 \mu \mathrm{L}$ of plasmids mix, to a final volume of $10 \mu \mathrm{L}$. Mix well. If more than 4 DNA parts are to be assembled into a pCk-pe vector, reduce the water volume in the MM 
by $1 \mu \mathrm{L}$ for each extra $1 \mu \mathrm{L}$ of DNA part added in the plasmids mix.

6 Place samples in a thermocycler and use the following program:

Assembly: 26 cycles of $37^{\circ} \mathrm{C}$ for $3 \mathrm{~min}$ and $16^{\circ} \mathrm{C}$ for 4 min.

Termination and enzyme denaturation: $50^{\circ} \mathrm{C}$ for $5 \mathrm{~min}$ and $80^{\circ} \mathrm{C}$ for $10 \mathrm{~min}$.

7 Transform $20 \mu \mathrm{L}$ of chemically competent E. coli cells (transformation efficiency of $1 \times 107$ transformants/ $\mu$ g plasmid DNA) using $2 \mu \mathrm{L}$ of the Loop assembly reaction and then plate on LB agar plates containing $100 \mu \mathrm{g} / \mathrm{mL}$ spectinomycin.

8 Incubate $\mathrm{O} / \mathrm{N}$ at $37^{\circ} \mathrm{C}$.

9 Colonies with white color are likely to contain the vector with the insert while yellow color colonies will contain the empty vector.

10 Confirm the presence of the correct insert with Sanger sequencing using the primers pC_F and PC_R 

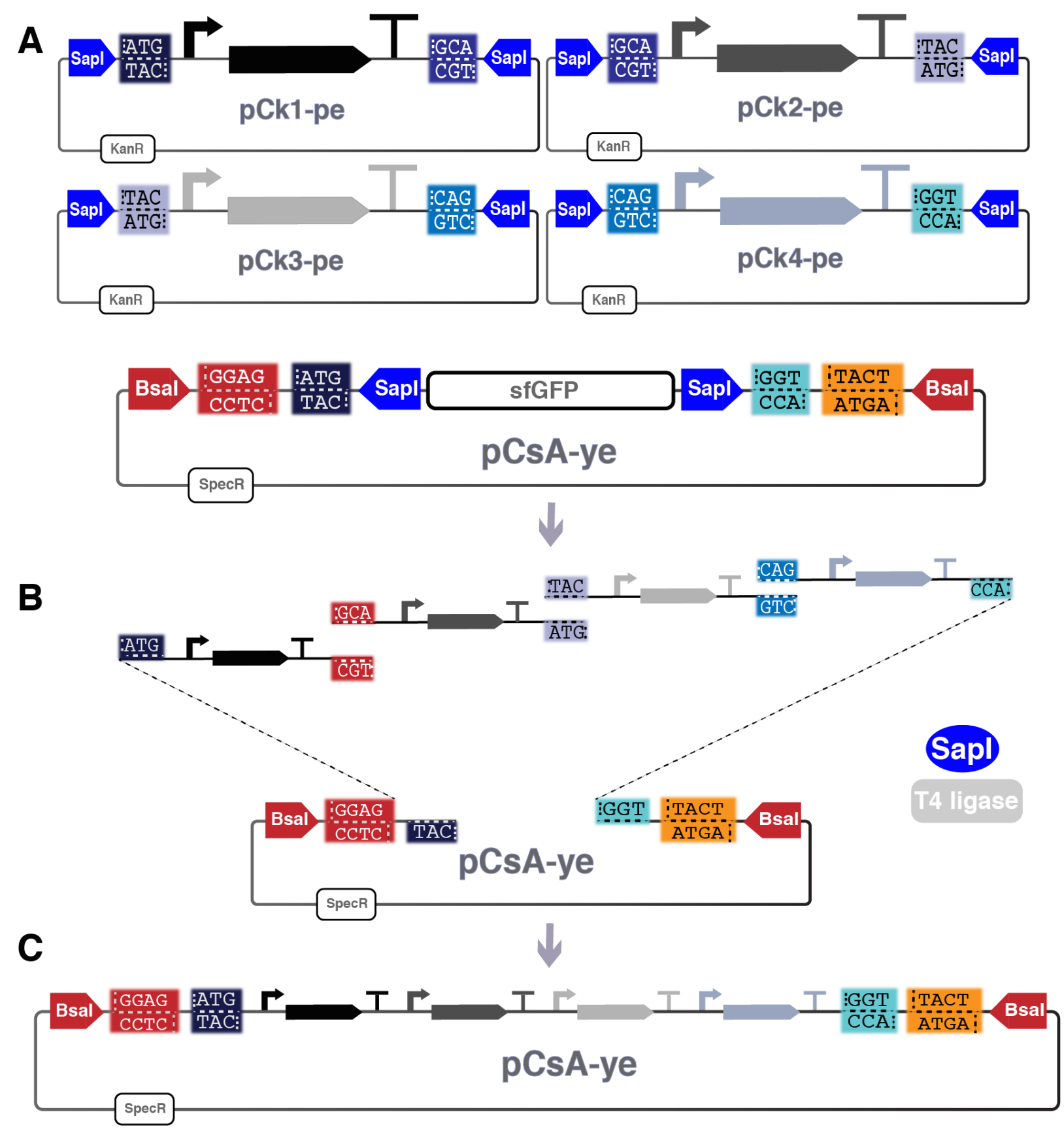
12

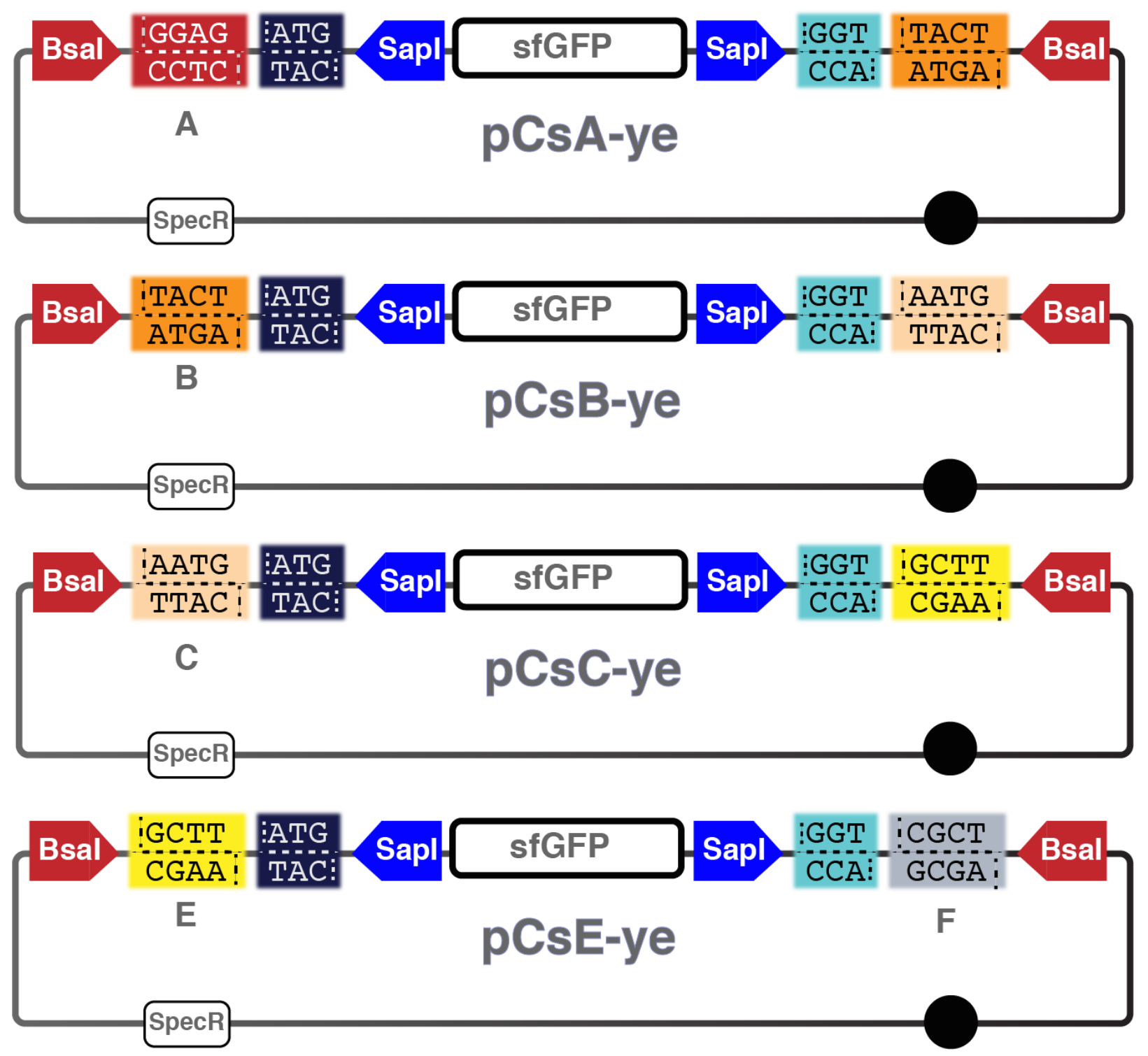

